\title{
Renal Disease in Primary Sjögren's Syndrome
}

Oshorenua Aiyegbusi · Laura McGregor · Lucy McGeoch •

David Kipgen · Colin C. Geddes · Kathryn I. Stevens

Received: October 28, 2020 / Accepted: November 26, 2020 / Published online: December 24, 2020

(C) The Author(s) 2020

\section{ABSTRACT}

Primary Sjögren's syndrome (pSS) is a chronic autoimmune disorder characterised by lymphocytic infiltration of the exocrine glands, predominantly the salivary and lacrimal glands, leading to sicca symptoms. Patients may have extraglandular disease involving multiple organs, including the kidneys. 5\% of patients with pSS can have renal involvement. Kidney disease in pSS presents a diagnostic challenge, as clinical symptoms are often insidious and can precede sicca symptoms. pSS affects the kidney through lymphocytic infiltration of renal tubules or immune complex deposition, leading to an array of clinical features. Tubulointerstitial nephritis is the most common histological pattern of kidney disease. Other tubular injuries

O. Aiyegbusi $(\varangle) \cdot$ C. C. Geddes · K. I. Stevens

Glasgow Renal and Transplant Unit, Queen

Elizabeth University Teaching Hospital, Glasgow,

UK

e-mail: Oshorenua.Aiyegbusi@ggc.scot.nhs.uk

L. McGregor · L. McGeoch

Glasgow Royal Infirmary, Glasgow, UK

D. Kipgen

Pathology Department, Queen Elizabeth University

Teaching Hospital, Glasgow, UK include renal tubular acidosis with hypokalaemia, Fanconi's syndrome and diabetes insipidus. Glomerular disease is less common and typically involves an immune complex-mediated process. Optimal treatment for kidney diseases in pSS is not established, and treatment is guided by the pattern of disease. For tubulointerstitial nephritis, management involves electrolyte imbalance correction and the use of immunosuppression, including steroids. Treatment of glomerular disease is targeted to the histological pattern, and often requires a combination of immunosuppressive agents. The risk of end-stage kidney disease is low. Nevertheless, patients with pSS and kidney disease have significantly reduced quality of life.

Keywords: Glomerulonephritis; Kidney disease; Sjögren's syndrome; Tubular dysfunction; Tubulointerstitial nephritis 


\section{Key Points}

Kidney disease occurs in 5\% of patients with primary Sjögren's syndrome, with a diverse spectrum of clinical manifestations.

Tubulointerstitial nephritis (TIN) and glomerulonephritis (GN) are the two most frequent kidney diseases.

Treatment is specific to kidney disease-it involves electrolyte abnormality correction as well as corticosteroids and other immunosuppressive agents, including B-cell depleting therapy.

Patients rarely develop end-stage kidney disease.

Regular screening is required to detect and prevent chronic kidney disease.

\section{DIGITAL FEATURES}

This article is published with digital features, including a summary slide, to facilitate understanding of the article. To view digital features for this article go to https://doi.org/10.6084/ m9.figshare.13286327.

\section{INTRODUCTION}

Sjögren's syndrome (SS) is a systemic autoimmune condition due to lymphocytic infiltration of exocrine glands. Infiltration of the salivary and lacrimal glands leads to the distinct sicca symptoms (dry eyes and mouth) associated with SS. It is the second most common chronic autoimmune rheumatological condition, and classically occurs in women during the fourth to fifth decade $[1,2]$.

SS can occur in isolation-primary Sjögren's syndrome (pSS)—or as secondary SS alongside other autoimmune disorders, including rheumatoid arthritis, scleroderma and systemic lupus erythematosus [3]. There is no single diagnostic test for SS; a diagnosis is made based on a combination of clinical features and laboratory results. The 2016 ACR/EULAR classification is the current diagnostic criterion for Sjögren's syndrome [4]. This robust criterion is the weighted sum of five objective items: antiRo/SSA positivity and lymphocytic sialadenitis on salivary gland biopsy, with a focus score of $\geq 1$ foci $/ \mathrm{mm}^{2}$ (each scoring 3 points), and tests for objective ocular and oral dryness (two ocular tests, including Schirmer's test, and an oral test, each scoring 1 point). A score of $\geq 4$ points in an individual with either ocular or oral dryness is diagnostic of SS.

$15 \%$ of patients with pSS exhibit extraglandular manifestations that affect many organs, including the lungs, skin, joints, nervous system and kidneys, contributing to the already high burden of illness and mortality [5]. Kidney disease occurs in 5\% of patients with pSS [6]. Symptoms vary from asymptomatic to electrolyte imbalances, kidney stones, renal insufficiency and nephrotic syndrome. Screening for kidney disease is included in the European League Against Rheumatism (EULAR) Sjögren's syndrome disease activity index (ESSDAI) [7]; a disease activity index used to measure disease activity in patients with SS. Tubulointerstitial nephritis (TIN) and glomerulonephritis (GN) are the two principal kidney diseases, with TIN accounting for $85 \%$ of patients with renal lesions [8].

This review will explore the clinical spectrum, treatment and outcomes of kidney disease in patients with pSS. This article is based on previously conducted studies and does not contain any new studies with human participants or animals performed by any of the authors. The peer-reviewed articles used for this review were obtained from PubMed or literature reviews.

\section{PREVALENCE OF PSS AND KIDNEY DISEASE}

It is difficult to accurately quantify the prevalence of kidney disease in pSS due to variability 
in study design and discrepancies in the definition of kidney involvement.

In 2015, using the 2002 diagnostic criteria [9] of the American-European Consensus Group (AECG) [10], Mariette et al. found that the prevalence of kidney disease worldwide ranged from 1 to $33 \%$. Updated in 2016 [4], this is the diagnostic criterion that is most commonly used in clinical research.

The prevalence of kidney disease in most European studies ranges between 4 and $7 \%$ (although an Italian prospective study reports a prevalence of 27\%), with seemingly higher prevalence in other ethnic groups [6, 11-14]. In a cohort of 573 Chinese patients with pSS, 34\% had kidney involvement [15], and a recent prospective study in India identified kidney disease in $50 \%$ of patients with pSS [16]. Disparities in diagnostic criteria, ethnicity and environmental factors may account for the observed variability [17].

Prospective studies in which patients were actively screened for renal tubular function report a higher prevalence of kidney disease. However, this is caveated with the recognition that some tubular abnormalities may not be clinically relevant, and it is impractical to conduct the complex investigations performed in those studies routinely.

According to histological findings, the prevalence is much lower, perhaps because most patients do not undergo kidney biopsy. Maripuri et al. [18] found that over a 30-year period, among 7276 patients with pSS, just $0.3 \%$ $(n=24)$ underwent kidney biopsy.

\section{SEROLOGICAL FINDINGS}

Patients with pSS and kidney disease have comparable incidences of ANA, anti-La/Ro and rheumatoid factor to those without kidney disease $[8,14,19]$. Hypergammaglobulinaemia is associated with distal renal tubular acidosis (dRTA), whilst low C3 levels and cryoglobulins are associated with GN $[8,12,19]$.

\section{SPECTRUM OF KIDNEY DISEASE}

\section{Tubular Dysfunction}

Renal tubular dysfunction can present in several ways, including hypokalaemia in association with renal tubular acidosis, Fanconi syndrome, Bartter syndrome, Gitelman syndrome and nephrogenic diabetes insipidus.

Hypokalaemia is a common finding in pSS, occurring in $30-47 \%$ of patients with kidney disease $[8,20]$ Hypokalaemia is usually asymptomatic but rarely presents as paralysis or respiratory arrest [8, 21]. Hypokalaemia occurs secondary to urinary potassium wasting in distal renal tubular acidosis (dRTA). The incidence of dRTA in pSS varies widely, and is quoted as between 5 and $70 \%$ in published series $[8,14,19,20]$. All patients with hypokalaemia and pSS who underwent kidney biopsy were found to have TIN $[20,22]$.

dRTA occurs when there is inadequate hydrogen ion excretion in the distal nephron (Fig. 1). Complete dRTA is characterised by normal anion gap metabolic acidosis, urine $\mathrm{pH}<5.5$, and is often associated with hypokalaemia. The underlying mechanism by which SS leads to dRTA is unclear. H-ATPase pumps are absent in immunohistochemical analysis of kidney tissue, and autoantibodies directed against carbonic anhydrase II (carbonic anhydrase deficiency results in dRTA) are found in patients with pSS $[23,24]$. dRTA may also be incomplete, with normal serum bicarbonate levels (distal acidification defect is insufficient to cause overt acidosis). Detection of this incomplete form requires measurement of urine $\mathrm{pH}$ following an exogenous acid load with ammonium chloride or during a furosemidebased urine acidification test. This is not convenient in routine clinical practice.

Rarely ( $\sim 3 \%)$, the proximal segment of the tubule can also be affected in pSS, leading to Fanconi syndrome (proximal tubular acidosis) [8]. The proximal tubules are responsible for the majority of the glomerular filtrate reabsorption. In addition to salt and water, the proximal tubules reabsorb glucose, amino acids, phosphate, urate and bicarbonate (Fig. 2). Fanconi 


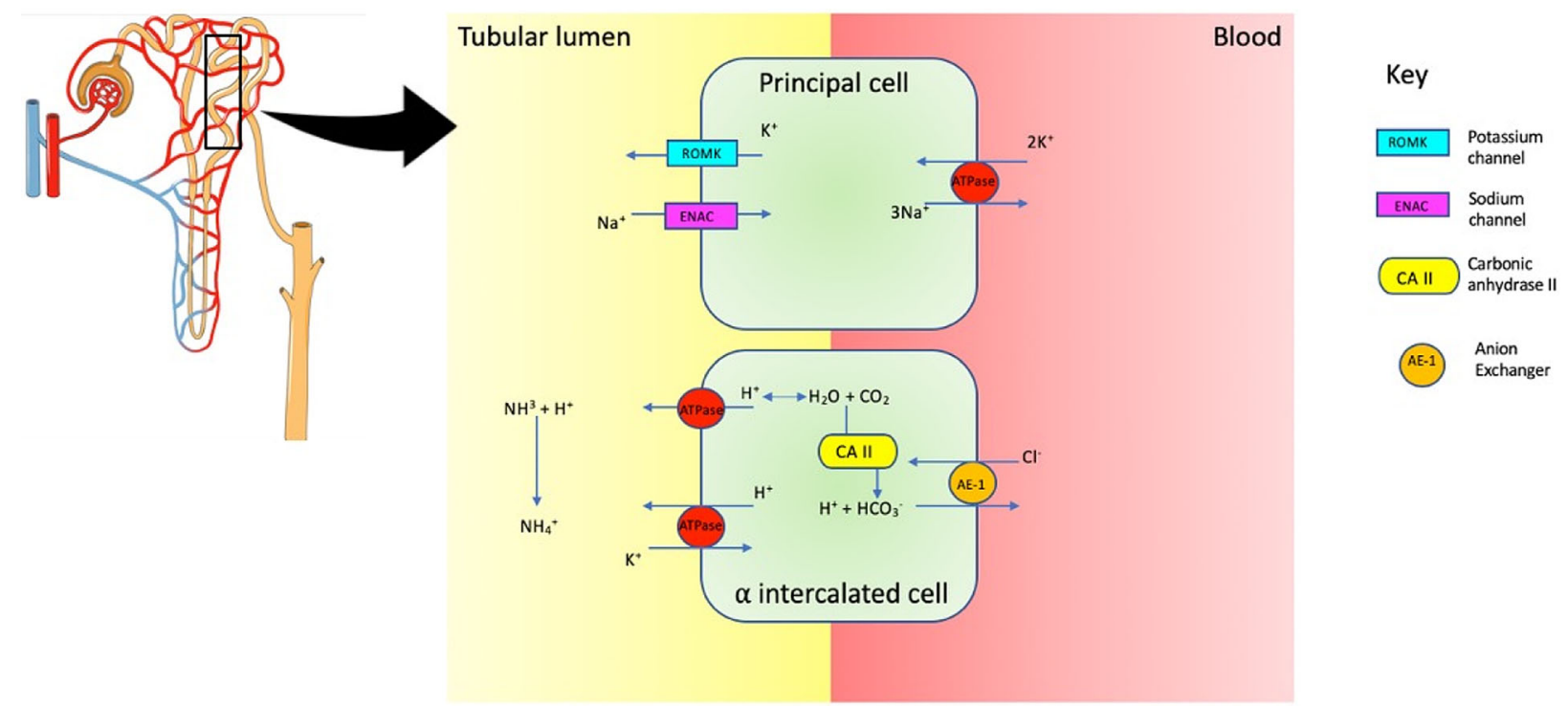

Fig. 1 Distal tubule. The $\alpha$-intercalated cell is responsible for $\mathrm{H}^{+}$secretion by $\mathrm{H}^{+} /$ATPase and $\mathrm{H}^{+} / \mathrm{K}^{+}$/ATPase. Ammonia $\left(\mathrm{NH}_{3}\right)$ buffers $\mathrm{H}^{+}$to form ammonium in the lumen. Intracellularly, $\mathrm{HCO}_{3}$ leaves cell via $\mathrm{Cl}^{-} / \mathrm{HCO}_{3}{ }^{-}$ exchange facilitated by AE1 (anion exchanger). Carbonic anhydrase II (CA II) is needed to secrete $\mathrm{H}^{+}$

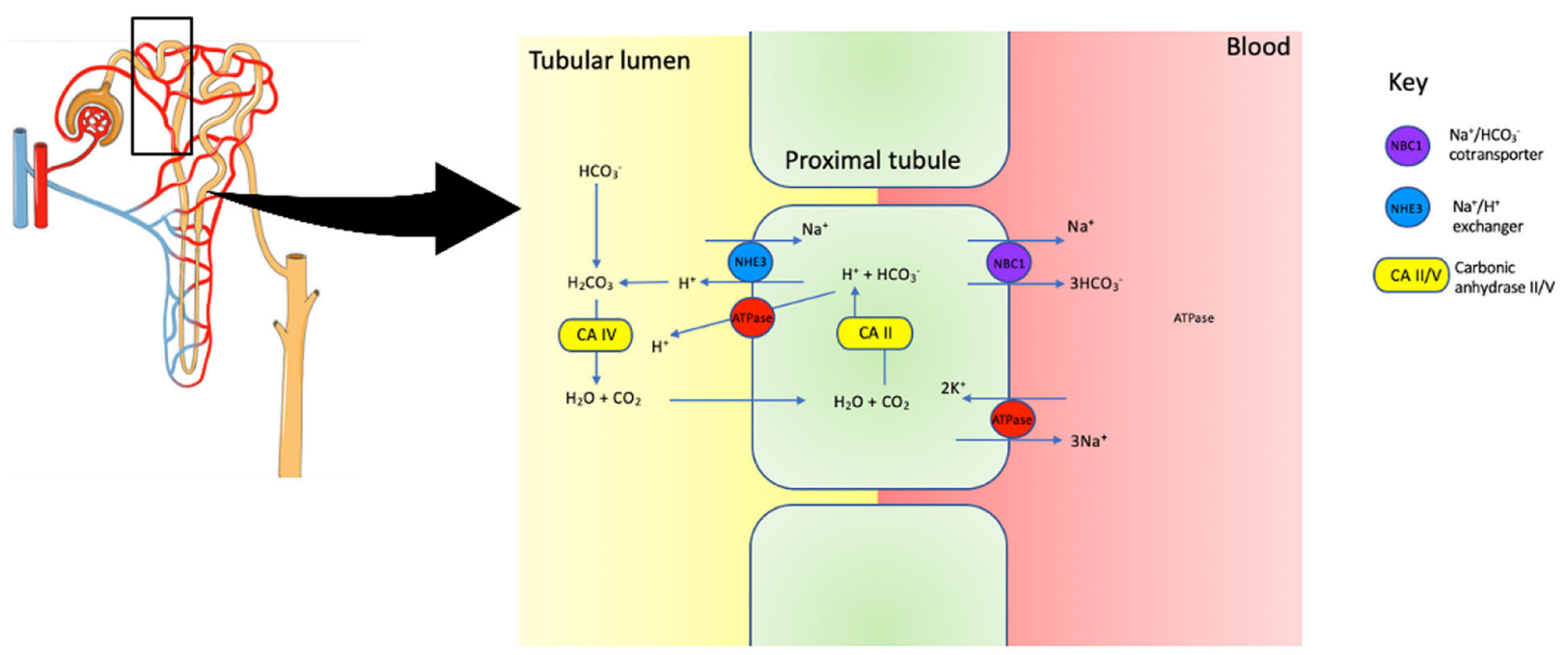

Fig. 2 Proximal tubule. Intracellular carbonic acid $\left(\mathrm{H}_{2} \mathrm{CO}_{3}{ }^{-}\right)$dissociates into $\mathrm{H}^{+}$and $\mathrm{HCO}_{3}{ }^{-}$under the action of carbonic anhydrase II (CAII). $\mathrm{H}^{+}$secretion is facilitated by $\mathrm{Na}^{+} / \mathrm{H}^{+}$exchanger, and $\mathrm{Na}^{+} / \mathrm{HCO}_{3}{ }^{-}$ cotransporter is responsible for $\mathrm{HCO}_{3}{ }^{-}$transport. In the lumen, $\mathrm{H}^{+}$reacts with $\mathrm{HCO}_{3}{ }^{-}$to form $\mathrm{H}_{2} \mathrm{CO}_{3}$, which

syndrome results in a normal anion gap metabolic acidosis accompanied by phosphaturia, glycosuria and aminoaciduria. Hypouricaemia dissociates into $\mathrm{H}_{2} \mathrm{O}$ and $\mathrm{CO}_{2}$ through the action of carbonic anhydrase V (CA V). Glucose, amino acids, phosphate and other substances are also reabsorbed through active and passive processes in the proximal tubule (mechanism not shown in schematic diagram). Damage in this region leads to Fanconi's syndrome

resulting from defective uric acid reabsorption frequently accompanies Fanconi syndrome.

Other acquired tubular defects such as Gitelman and Bartter syndromes rarely occur in 


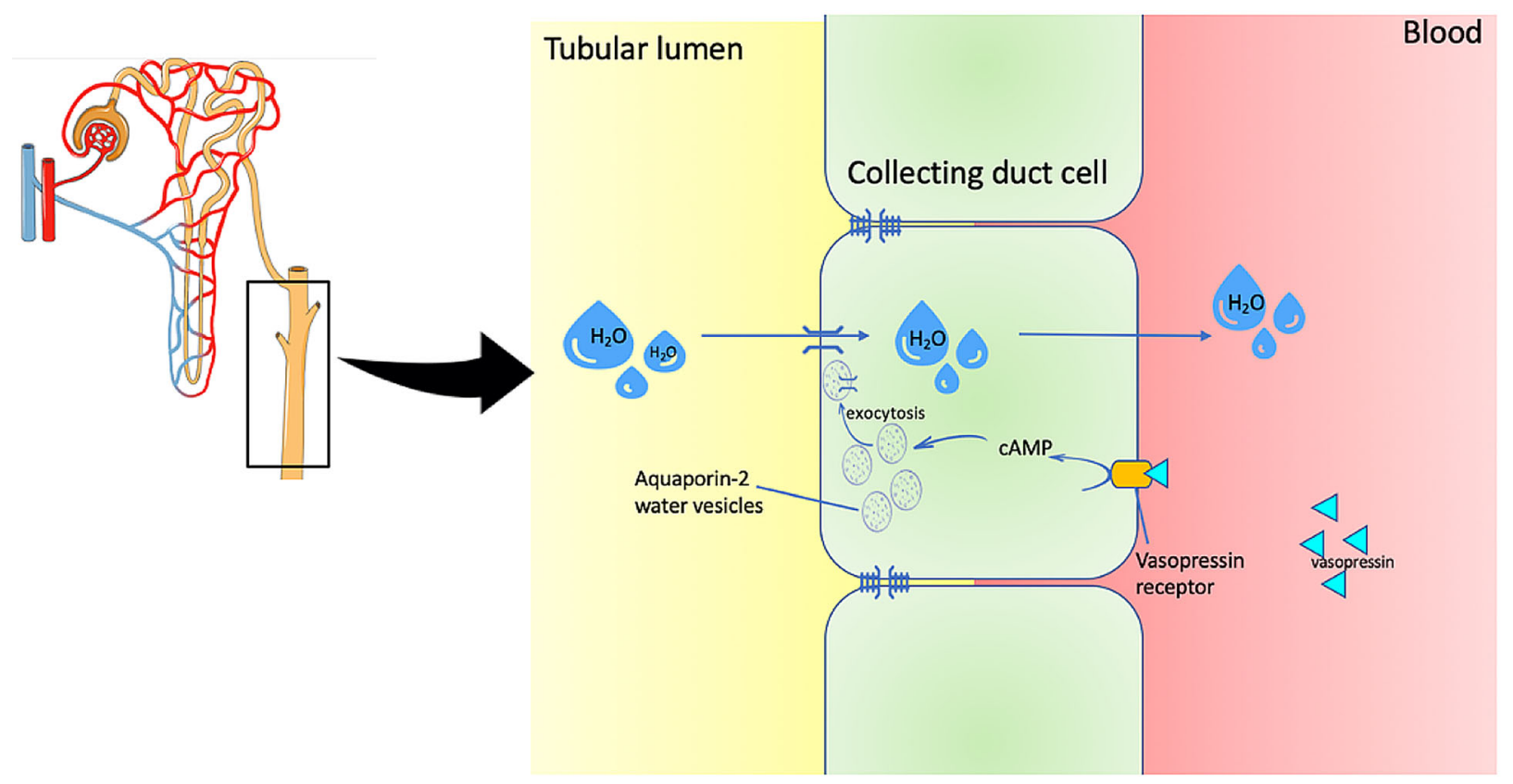

Fig. 3 Collecting duct. Vasopressin (ADH) binds to vasopressin receptor on collecting duct cells, leading to activation of the extracellular cAMP-adenosine pathway and subsequently to fusion of vesicles containing the water channel protein AQP2 (aquaporin 2) to the apical

pSS. The clinical features of Gitelman and Bartter syndromes resemble the clinical features of chronic thiazide or loop diuretic ingestion, respectively. Gitelman syndrome is a salt-wasting tubulopathy characterised by alkalosis, hypokalaemia, hypomagnesaemia, hypercalciuria and secondary hyperaldosteronism. There are a few isolated case reports of acquired Gitelman associated with pSS [25-27]. In Gitelman syndrome, there is loss of function of the thiazide-like sodium-chloride cotransporter (NCCT) expressed in the distal convoluted tubules. In pSS, autoantibodies to NCCT have been described [26]. Bartter syndrome is even less frequently reported in pSS $[28,29]$. It is a manifestation of reduced sodium chloride reabsorption in the thick ascending limb of the loop of Henle. It also leads to alkalosis, hypokalaemia and secondary hyperaldosteronism. Hypomagnesaemia may occur but, unlike in Gitelman syndrome, urine calcium excretion is normal or high. The underlying membrane. Water is then absorbed by osmosis into the bloodstream. Deficiency in vasopressin due to diabetes insipidus impedes this process

pathophysiology of Bartter syndrome in pSS is yet to be established [30, 31].

\section{Nephrogenic Diabetes Insipidus}

Nephrogenic diabetes insipidus is the inability to concentrate urine due to impaired tubular response to vasopressin (ADH); usually confirmed by the water deprivation test (Fig. 3). Renal concentrating defects have been described in pSS, and present with polydipsia, polyuria and nocturia $[8,14,20]$. In an Italian cohort, a quarter of pSS patients had a urineconcentrating defect [14]. Comparably, 38\% had urine concentration disorders in a Chinese study, and 3 patients had nephrogenic diabetes insipidus-associated dRTA [8].

\section{Nephrolithiasis}

$14-25 \%$ of patients with pSS have stone disease (Fig. 4), with nearly all patients experiencing renal colic $[12,18,20]$. Nephrolithiasis 

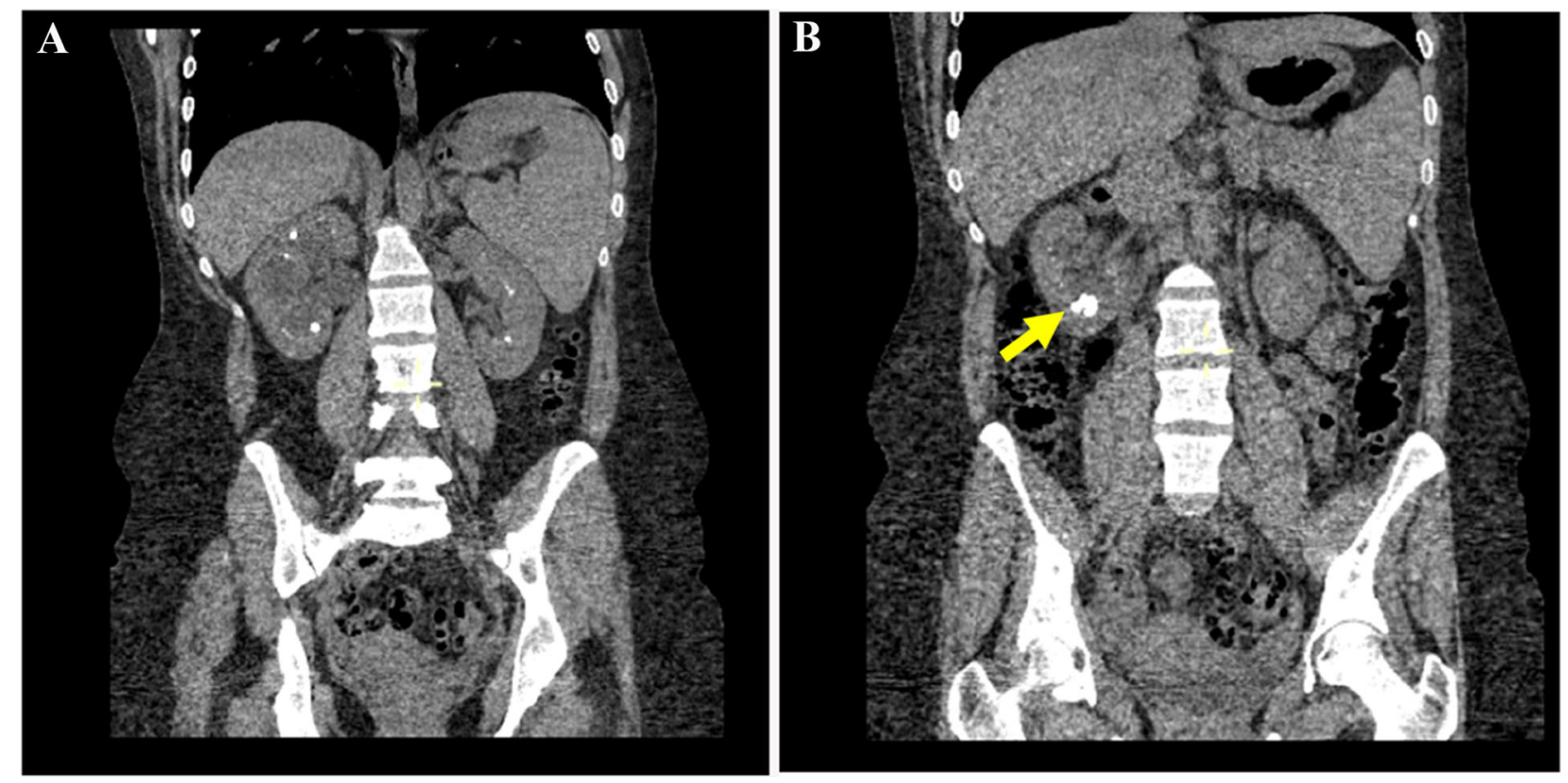

Fig. 4 CT imaging of a patient with Sjögren's syndrome showing a bilateral medullary nephrocalcinosis and $\mathbf{b}$ calculi in the right kidney (arrow)

occurs secondary to the hypercalciuria and hypocitraturia accompanying dRTA. As a consequence of acidaemia, calcium phosphate is released from bone and its precipitation is promoted in alkaline urine. Hypocitraturia also leads to calcium-containing stones, as citrate is a potent inhibitor of calcium stone formation.

A renal tract ultrasound is necessary to exclude obstructive uropathy in patients presenting with renal colic and acute kidney injury. Very rarely, kidney biopsy is required. TIN is the predominant histological finding in patients with renal colic and radiological features of nephrolithiasis [12]. TIN with nephrocalcinosis was seen on kidney biopsy in all patients $(n=2)$ presenting with chronic kidney disease (CKD) [22]. One patient had hypercalcaemia, but sarcoidosis was evident on kidney biopsy.

\section{Tubulointerstitial Nephritis}

Lymphocytic infiltration leading to acute or chronic TIN is the principal kidney manifestation in pSS $[18,20,22]$. About $75 \%$ of pSS patients undergoing a kidney biopsy will have TIN $[8,18]$. It is thought that infiltration in the renal tubules is primarily by $\mathrm{CD} 4+\mathrm{T}$ lymphocytes, similar to the pathophysiological process in salivary glands $[32,33]$. CD8+ T cells and plasma cell infiltration can also be present $[14,34]$. In $10 \%$ of cases, B cells are the predominant cell type [10]. Granulomas, though infrequently seen, suggest the presence of sarcoidosis $[18,22]$.

The manifestation of TIN is variable. Patients can present with tubular dysfunction as described, but also acute kidney injury (AKI) or a slow progressive deterioration in kidney function [18]. TIN may remain undiagnosed due to its indolent clinical course; interstitial inflammation is often accompanied by fibrosis and tubular atrophy on renal biopsy $[8,18]$. TIN can occur prior to the onset of sicca symptoms, so pSS should be considered in patients with TIN and hypokalaemia [20].

\section{Glomerular Disease}

Glomerular involvement is less common than tubular disease in pSS. AKI, rapidly progressive GN with nephritic syndrome, CKD, and nephrotic syndrome can occur. Nephritic syndrome occurs as a result of damage to the renal 


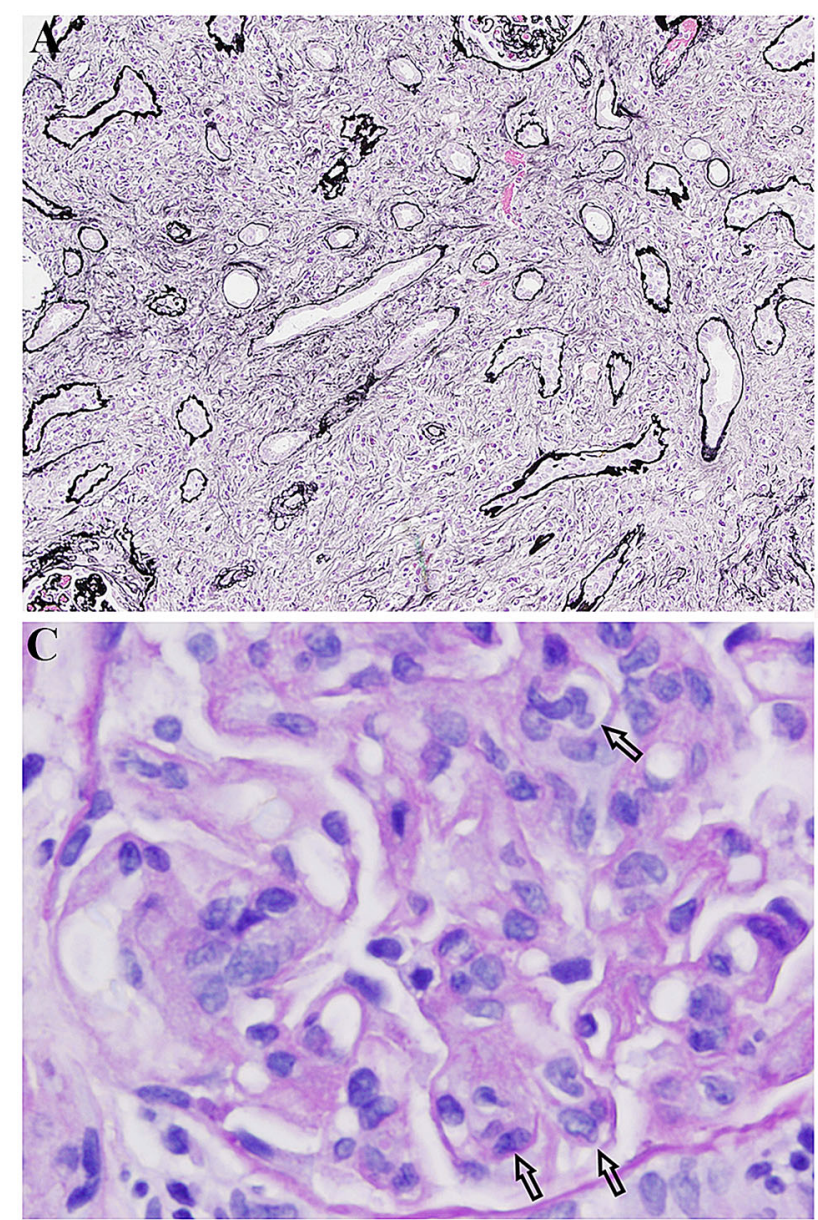

Fig. 5 a IgG4-related tubulointerstitial nephritis: tubules separated by expansile interstitial fibrosis and inflammation. Jones methenamine silver, $\times 4$. This image was originally used in Kidder et al. [22]. b IgG4-related tubulointerstitial nephritis: interstitial "storiform" fibrosis and inflammation. Haematoxylin and eosin stain, $\times 40$. This image was originally used in Kidder et al. [22]. c Membranoproliferative glomerulonephritis in Sjögren's:

endothelium, causing haematuria and proteinuria (typically $<3 \mathrm{~g} /$ day) accompanied by AKI, oliguria and hypertension. By contrast, nephrotic syndrome is characterised by a triad of heavy proteinuria ( $>3 \mathrm{~g} /$ day, equivalent to a urine protein:creatinine ratio $>300 \mathrm{mg} / \mathrm{mmol}$ ), hypoalbuminaemia (serum albumin $\leq 30 \mathrm{~g} / \mathrm{L}$ ) and peripheral oedema. Nephrotic syndrome is a feature of damage initially to the podocytes and glomerular basement membrane.

Membranoproliferative glomerulonephritis (MPGN) is the most frequently reported
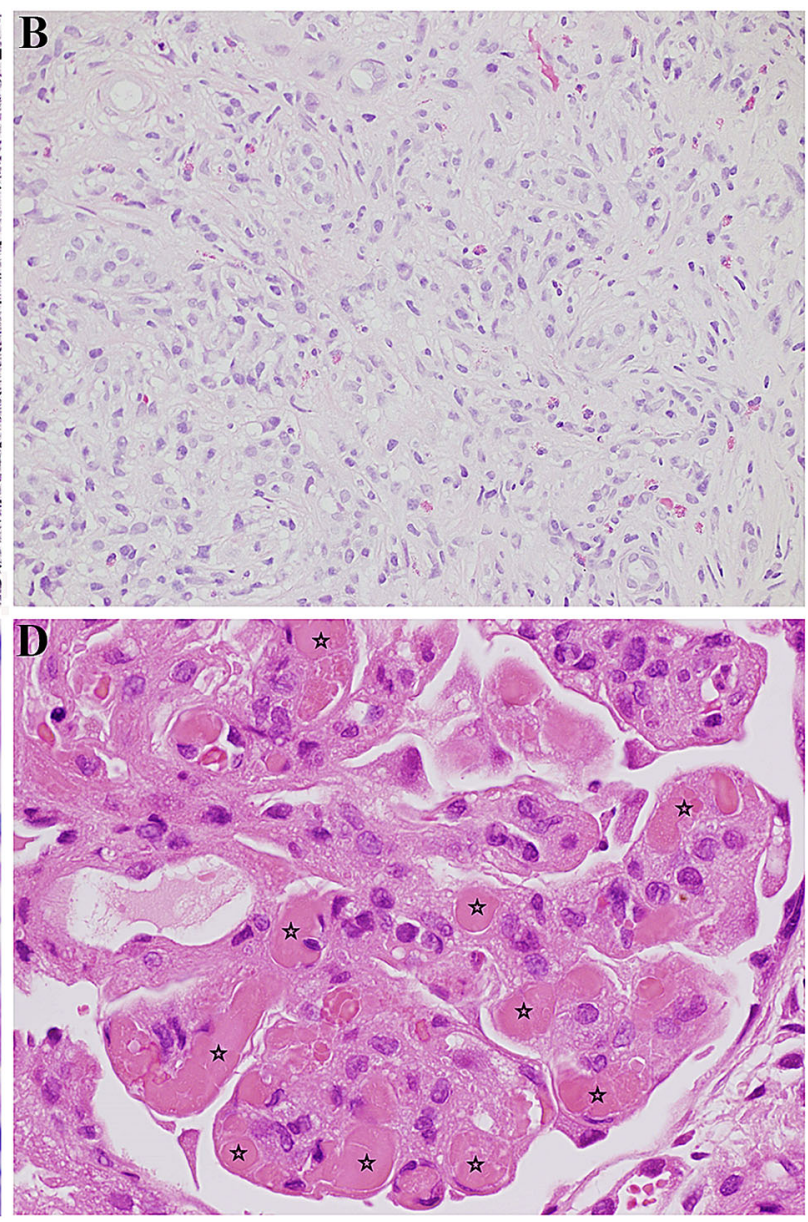

glomerulus showing intracapillary hypercellularity (indicated by arrows) (PAS, $\times 400)$. This image was originally used in Kidder et al. [22]. d Cryoglobulinaemic glomerulonephritis in Sjögren's: glomerulus containing several hyaline thrombi, "cryoplugs" (indicated by stars), in capillaries. $\mathrm{H}+\mathrm{E}, \times 400$. This image was originally used in Kidder et al. [22].

glomerular lesion (Fig. 5c). Other glomerular diseases have also been reported, such as minimal change disease, IgA nephropathy, focal segmental glomerulosclerosis, membranous nephropathy, fibrillary GN and vasculitis $[8,14,20,22]$. It is possible that, rather being than features of the pSS disease process itself, these other glomerular lesions coexist with pSS.

MPGN is an immune-mediated process leading to immune complex deposition in the glomeruli. Autoimmune diseases, infections and cancers can all cause MPGN. In pSS, the 
mechanism of glomerular lesions is thought to be related to immune complex deposition, C4 consumption due to activation of the classical complement pathway, and cryoglobulinaemia [8].

Cryoglobulins are cold-sensitive immunoglobulins that cause systemic inflammation through immune complex deposition alone or in association with another disease process such as rheumatoid arthritis, scleroderma or hepatitis C. In one study, cryoglobulins were detected in the serum in approximately two-thirds of patients with pSS and kidney involvement; the majority (88\%) of these patients had an underlying GN on kidney biopsy [12]. Cryoglobulin deposition is present on kidney tissue (Fig. 5d) [14, 22]. Overall, 14\% of patients with pSS have coexisting hepatitis C virus. However, if a patient with pSS has cryoglobulinaemia, hepatitis $\mathrm{C}$ infection is far more prevalent, affecting approximately $50 \%$ of these patients [35, 36].

ANCA-associated vasculitis (AAV) has been described in pSS. Antineutrophil cytoplasmic antibodies (ANCA) are prevalent in $6-7 \%$ of patients with pSS [37]. In a French case series and literature review of patients with both AAV and pSS, 59\% $(n=13)$ patients had kidney involvement. Eleven patients had kidney biopsy findings consistent with ANCA glomerulonephritis-all cases had anti-myeloperoxidase antibody positivity (anti-MPO).

Studies in populations with different ethnicities have shown some inconsistencies. For instance, glomerular lesions appear less common in Asian patients, occurring in just 14\% $(18 / 130)$ in a Chinese cohort [8]. In contrast, early/mild glomerular changes were seen in $35 \%(n=6 / 17)$ of an Indian population [16], whilst 29\% $(n=7 / 24), 36 \%(n=9 / 25)$ and $49 \%$ $(n=17 / 35)$ of patients in American, Scottish and Greek series, respectively, had histological evidence of GN $[12,18,22]$. MPGN was the predominant glomerular lesion in all studies. It is difficult to know if these variations represent true discrepancies in the disease across ethnicity and geographical cohorts or differences in perceptions of indication for kidney biopsy in different countries.

\section{IgG4-Related Disease}

Immunoglobulin G4-related disease (IgG4-RD) is a rare immune-mediated fibroinflammatory condition which can affect multiple organs and is characterised by inflammatory tissue deposition in various organs. It can be associated with elevated serum IgG4 concentrations [38]. Histology is crucial in the diagnosis of IgG4RD. Key features of the disease include tissue fibrosis with a storiform pattern, diffuse lymphoplasmacytic infiltrate (mainly IgG+ plasma cells) and moderate tissue eosinophilia (Fig. 5a and b) [39]. Retroperitoneal fibrosis and microvascular manifestations such as large-vessel vasculitis of the aorta also occur in IgG4-RD [40].

There are similarities between IgG4-RD and pSS: sicca symptoms, arthralgia, hypergammagobulinaemia and hypocomplementaemia may be present. This can make differentiation challenging.

Compared with pSS, IgG4-RD exhibits a male predominance, serum IgG4 levels are often elevated, and anti-Ro and anti-La antibodies are found infrequently. Histologically, a characteristic storiform-like fibrosis is evident and often, unlike in pSS, there is a clinical response to corticosteroid [38]. In IgG4-RD, salivary glands contain IgG4+ plasma cells.

$8 \%$ of patients with pSS have elevated serum IgG4 levels and IgG4+ staining is present in kidney biopsy samples [41-43]. Normalising serum IgG with immunosuppressive treatment is considered the therapeutic goal for this subgroup of patients [32]. Whether this is a distinct subtype of pSS or these two disorders coexist is uncertain. A histological diagnosis and clinical features are essential to discriminate between both disease processes.

\section{Progressive CKD}

$20-28 \%$ of patients present with chronically reduced kidney function $[20,22]$. A retrospective biopsy series found that a progressive decline in kidney function occurred in $15 \%$ of patients [22]. Recently, a large Taiwanese cohort study indicated that patients with pSS are more 
likely to develop CKD compared with the general population (adjusted $\mathrm{HR}, 1.49 ; 95 \% \mathrm{CI}$, 1.38-1.59) [44]. However, the risk of developing end-stage kidney disease (ESKD) was low and similar to the risk identified in population controls (incidence 0.43 vs 0.58 per 1000 person-years in pSS and a matched control cohort, respectively).

For the few patients that develop ESKD, kidney transplantation is the optimal form of renal replacement therapy. In $\mathrm{GN}$, there is varying risk of recurrence of the original disease in the transplant kidney; this has the potential to result in serious morbidity, including transplant failure. Disease recurrence rates after kidney transplantation are $10 \%$ and $40 \%$ for AAV and MPGN, respectively $[45,46]$. Although common among kidney transplant recipients (70\%), the presence of serum cryoglobulins does not affect graft outcomes [47]. On the other hand, all patients with cryoglobulinaemia-associated glomerulonephritis seem to develop disease recurrence; this, however, does not preclude kidney transplantation [48-50]. A case report of cryoglobulinaemia causing graft dysfunction two months following kidney transplantation has been described in a patient with pSS [51]. In this case, biopsy-proven chronic tubulointerstitial nephritis was confirmed in native kidneys, suggesting de novo disease.

\section{KIDNEY BIOPSY IN PRIMARY SJÖGREN'S SYNDROME}

Percutaneous kidney biopsy is performed for various reasons in kidney disease, but usually to establish diagnosis and guide management. Major bleeding, which occurs in 2\%, is the primary complication of a kidney biopsy [52]. The coagulation screen is always checked in advance, and steps are taken to minimise bleeding risk, including withholding anticoagulation and controlling blood pressure. When bleeding occurs, it is commonly transient haematuria, but $0.4 \%$ of patients require angiographic intervention [52].

Generally, a kidney biopsy should be undertaken when the histological findings will alter management and influence treatment. In patients with pSS who have preserved renal excretory function and tubular abnormalities such as hypokalaemia, the underlying pathology is presumed to be TIN, and kidney biopsy is not usually undertaken (Table 1). Kidney biopsy should be considered when there is AKI and/or urinary abnormalities.

\section{WHEN TO REFER TO NEPHROLOGY}

As kidney disease impacts the patient's prognosis and quality of life, diagnosis is essential (Fig. 6). The ESSDAI score classifies kidney disease activity if there is any evidence of active disease. A kidney biopsy is not mandatory; however, if performed, histology directs the activity score. Urinalysis (proteinuria, haematuria and urinary $\mathrm{pH}$ ) together with serum tests (creatinine and electrolytes, including phosphate, urate and bicarbonate) are required to monitor activity. Kidney involvement due to other diseases is not taken into account in the ESSDAI activity profile. Patients with RTA are scored as low in the absence of kidney failure or glomerular involvement (proteinuria, haematuria). If present, the score is moderate [53]. Glomerular disease is recorded as low, moderate or high depending on the degree of proteinuria $(<1,1-1.5$ and $>1.5 \mathrm{~g} /$ day, respectively) [53].

In cases where kidney function is normal, yearly monitoring is encouraged, as disease can occur at any stage. When there are anomalies or reduced kidney function, monitoring may need to be more frequent and should be guided by the individual patient. For patients with stable CKD and eGFR between 30 and $60 \mathrm{ml} /$ $\min / 1.73 \mathrm{~m}^{2}$, we recommend six-monthly screening. CKD stage 4 and 5 (eGFR $<30 \mathrm{ml} /$ $\min / 1.73 \mathrm{~m}^{2}$ ) is best managed with a multidisciplinary approach that includes nephrology physicians. Renal tract ultrasound should be performed to exclude nephrolithiasis and obstructive nephropathy. If electrolyte disturbances are severe or there is evidence of kidney disease (proteinuria, haematuria, elevated creatinine) then referral to nephrology is recommended. 
Table 1 Summary of published series, serology status and kidney biopsy findings in primary Sjögren's syndrome

\begin{tabular}{|c|c|c|c|c|c|c|}
\hline Study & $\begin{array}{l}\text { Diagnostic } \\
\text { criteria }\end{array}$ & $\begin{array}{l}\text { Total } \\
\text { number of } \\
\text { patients }\end{array}$ & $\begin{array}{l}\text { Number of } \\
\text { patients with } \\
\text { kidney biopsy }\end{array}$ & $\begin{array}{l}\text { Serology (of available } \\
\text { results) }\end{array}$ & $\begin{array}{l}\text { TIN } \\
\text { (percentage of } \\
\text { total biopsies) } \\
(\%)\end{array}$ & $\begin{array}{l}\text { GN } \\
\text { (percentage of } \\
\text { total biopsies) } \\
(\%)\end{array}$ \\
\hline $\begin{array}{l}\text { Goules } \\
\text { et al. } \\
\text { [63] } \\
(2000)\end{array}$ & $\begin{array}{c}\text { European } \\
\quad(1993)\end{array}$ & 20 & 18 & $\begin{array}{l}\text { ANA } 100 \% \\
\text { Anti-Ro } 75 \% \\
\text { Anti-La } 50 \% \\
\text { RF } 75 \% \\
\text { Low C3 10\% } \\
\text { Low C4 40\% } \\
\text { Cryoglobulins 50\% }\end{array}$ & 55 & 40 \\
\hline $\begin{array}{l}\text { Bossini } \\
\text { et al. } \\
{[14]} \\
(2001)\end{array}$ & $\begin{array}{c}\text { European } \\
(1993)\end{array}$ & 60 & 9 & $\begin{array}{l}\text { ANA } 85 \% \\
\text { Anti-Ro } 80 \% \\
\text { Anti-La } 40 \% \\
\text { RF } 82 \% \\
\text { Low C3 8\% } \\
\text { Low C4 18\% } \\
\text { Cryoglobulins 13\% } \\
\text { Hypergammaglobulins } \\
72 \%\end{array}$ & 67 & 33 \\
\hline $\begin{array}{l}\text { Ren et al. } \\
\quad[8] \\
(2008)\end{array}$ & $\begin{array}{l}\text { AECG } \\
(2002)\end{array}$ & 130 & 41 & $\begin{array}{l}\text { Anti-Ro 51\% } \\
\text { Anti-La 38\% } \\
\text { RF 58\% } \\
\text { Low C3 44\% } \\
\text { Low C4 15\% } \\
\text { Hypergammaglobulins } \\
71 \%\end{array}$ & 80 & 20 \\
\hline $\begin{array}{l}\text { Maripuri } \\
\text { et al. } \\
{[18]} \\
(2009)\end{array}$ & $\begin{array}{l}\text { AECG } \\
\quad(2002)\end{array}$ & 24 & 24 & $\begin{array}{l}\text { Anti-Ro or anti-La } \\
\quad 83 \% \\
\text { RF } 80 \% \\
\text { Cryoglobulins } 13 \%\end{array}$ & 71 & 21 \\
\hline
\end{tabular}


Table 1 continued

\begin{tabular}{|c|c|c|c|c|c|c|}
\hline$\overline{\text { Study }}$ & $\begin{array}{l}\text { Diagnostic } \\
\text { criteria }\end{array}$ & $\begin{array}{l}\text { Total } \\
\text { number of } \\
\text { patients }\end{array}$ & $\begin{array}{l}\text { Number of } \\
\text { patients with } \\
\text { kidney biopsy }\end{array}$ & $\begin{array}{l}\text { Serology (of available } \\
\text { results) }\end{array}$ & $\begin{array}{l}\text { TIN } \\
\text { (percentage of } \\
\text { total biopsies) } \\
(\%)\end{array}$ & $\begin{array}{l}\text { GN } \\
\text { (percentage of } \\
\text { total biopsies) } \\
(\%)\end{array}$ \\
\hline $\begin{array}{l}\text { Goules } \\
\text { et al. } \\
{[12]} \\
(2013)\end{array}$ & $\begin{array}{l}\text { AECG } \\
(2002)\end{array}$ & 715 & 35 & $\begin{array}{l}\text { Anti-Ro 69\% } \\
\text { Anti-La 43\% } \\
\text { RF 63\% } \\
\text { Low C3 26\% } \\
\text { Low C4 54\% } \\
\text { Cryoglobulins 45\% } \\
\text { Hypergammaglobulins } \\
82 \%\end{array}$ & 37 & 49 \\
\hline $\begin{array}{l}\text { Kidder } \\
\text { et al. } \\
{[22]} \\
(2015)\end{array}$ & $\mathrm{n} / \mathrm{a}$ & 25 & 25 & $\begin{array}{l}\text { ANA } 74 \% \\
\text { Anti-Ro/La } 63 \% \\
\text { RF } 52 \% \\
\text { Hypergammaglobulins } \\
66 \%\end{array}$ & 48 & 32 \\
\hline $\begin{array}{l}\text { Jain et al. } \\
\qquad \begin{array}{l}\text { [16] } \\
(2018)\end{array}\end{array}$ & $\begin{array}{l}\text { AECG } \\
(2002)\end{array}$ & 70 & 17 & $\begin{array}{l}\text { ANA } 100 \% \\
\text { Anti-Ro } 97 \% \\
\text { Anti-La } 71 \% \\
\text { RF } 83 \% \\
\text { Low C3/C4 20\% }\end{array}$ & 24 & 6 \\
\hline $\begin{array}{l}\text { Goules } \\
\text { et al. } \\
\text { [20] } \\
(2019)\end{array}$ & $\begin{array}{l}\text { AECG } \\
(2002)\end{array}$ & 20 & 12 & $\begin{array}{l}\text { ANA 50\% } \\
\text { RF 68\% } \\
\text { Low C3 30\% } \\
\text { Low C4 55\% } \\
\text { Cryoglobulins 19\% }\end{array}$ & 59 & 33 \\
\hline
\end{tabular}

AECG American-European Consensus Group, GN glomerulopathy, TIN tubulointerstitial nephritis

\section{TREATMENT OF PSS-ASSOCIATED KIDNEY DISEASE}

CKD is an independent risk factor for cardiovascular (CV) disease. Thus, general management of all kidney disease involves reducing $\mathrm{CV}$ risk in addition to preventing or slowing the rate of decline in kidney function. This is achieved through regular monitoring, optimising blood pressure, minimising proteinuria, controlling modifiable CV risk factors (e.g. smoking) and treating reversible causes of kidney disease. 


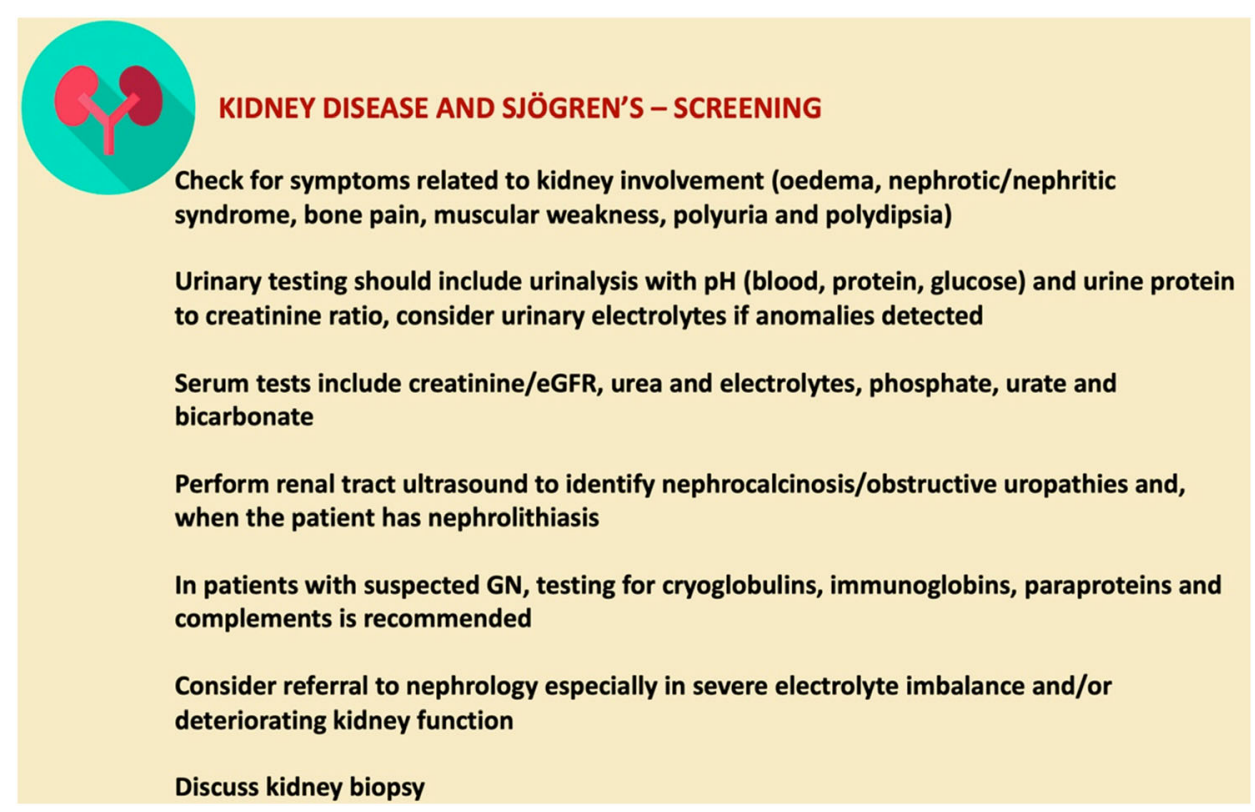

Fig. 6 Guide to screening for renal involvement in primary Sjögren’s syndrome. Adapted from Ramos-Casals et al. [6]

Treatment of kidney disease associated with pSS is very much dependent upon the disease process. In patients with dRTA, treatment is largely supportive and involves correction of acidosis and hypokalaemia with bicarbonate and potassium supplements.

Immunosuppressive therapy to reduce inflammation and the development of fibrosis may be initiated in certain circumstances. Immunosuppressive treatment options are disease specific but may include corticosteroids, antiproliferative agents, calcineurin inhibitors, cyclophosphamide and B-cell depletion therapy [10].

\section{Tubulointerstitial Nephritis}

The question of who will benefit from steroid treatment in pSS-associated TIN is unclear. Often, chronic inflammation, interstitial fibrosis and tubular atrophy are seen on kidney biopsy due to a delayed diagnosis; these patients do not typically benefit from corticosteroids. In a study from Kidder et al. [22], 54\% $(n=7 / 13)$ of patients with biopsy-proven TIN received corticosteroids and had good clinical outcomes. Only one patient in this group had steroids and mycophenolate mofetil (MMF). Additional therapy was required in patients with coexisting kidney disease (14\%)—azathioprine with MPGN and hydroxychloroquine with sarcoidosis.

A similar approach was adopted in another study where nearly all patients (95\%) with TIN received prednisolone with a median initial dose of $40 \mathrm{mg}$ (range 30-60 mg) [18]. In addition to corticosteroids, 2 patients (11\%) received cyclophosphamide while 1 patient received rituximab (at the time of biopsy); the indication for rituximab was not stated. Of the 15 patients who received treatment, 60\% achieved a $>20 \%$ improvement in kidney function.

Corticosteroids are the preferred choice of treatment in TIN. Other treatment options are considered in patients who are intolerant of steroids or those with refractory disease. MMF inhibits the proliferation of $\mathrm{B}$ and $\mathrm{T}$ lymphocytes-key players in the lymphocyte-rich infiltration associated with pSS. In a case series of patients with TIN in pSS, MMF yielded a significant improvement in kidney function [32]. The optimal dose of MMF is unknown, but doses of $1-3 \mathrm{~g}$ daily were used in the study. A low or short weaning course of corticosteroids in addition to MMF was the favoured regime. 
Another study observed conflicting results, with no clinical benefit in patients with TIN who received immunosuppressive agents (mainly a combination of prednisolone and MMF) [20]. Only 25\% saw an improvement of $>20 \%$ from baseline renal function. In addition, there was no improvement in renal colic frequency, hypokalaemia or other features of dRTA.

Rituximab, a monoclonal anti-CD20 antibody, is increasingly used in both systemic and kidney conditions. Interest in rituximab and pSS originates from the role of B cells in the disease pathogenesis, but results from randomised control trials in patients with or without extraglandular manifestations are conflicting [54-57]. When rituximab was used, it was primarily to treat worsening sicca symptoms rather than kidney disease [18].

Rituximab is infrequently required in TIN and is more likely to be used in glomerular disease, as discussed below. In a case of TIN with recurrent kidney stones secondary to dRTA, rituximab improved excretory renal function and corrected the tubular defect [58].

\section{Glomerular Disease}

With glomerular involvement, treatment is based on the pathological lesion. Generally, angiotensin-converting enzyme inhibitors and angiotensin II receptor blockers are favoured for blood pressure control and anti-proteinuric effects (particularly nephrotic-range proteinuria).

A patient with glomerular disease is likely to require more than one immune therapy [22]. The choice of immunosuppressive agent in pSSassociated glomerular disease varies amongst clinicians. A combination of corticosteroid with an antiproliferative/alkylating agent or rituximab are reasonable treatment options that are dictated by the glomerular lesion and clinical judgement. Half of patients require at least three immune agents; corticosteroid, MMF and rituximab were the most frequent combination $[18,22]$. Cyclophosphamide in combination with corticosteroids is also used [12, 22].
In a Scottish study, one-third of patients achieved complete remission (defined by normalisation of serum creatinine and resolution of urinary sediment abnormalities) following treatment, and $40 \% \quad(n=4 / 9) \quad$ maintained stable kidney function after treatment [22]. However, in a Greek cohort, all patients $(n=5)$ had either stable or improved kidney function [20].

Rituximab appears to have a role in cryoglobulinaemia. Rituximab plus corticosteroid with or without antiproliferative/alkylating agent, is preferred in noninfectious cryoglobulinaemia associated with pSS [22, 59]. A large French multicenter study (CryoVas) of noninfectious cryoglobulinaemic vasculitis showed that rituximab plus corticosteroid combination therapy was superior to either corticosteroid monotherapy or corticosteroid in combination with an alkylating agent [59]. Patients with pSS represented a quarter of the cohort in this study.

Plasmapheresis is considered in refractory autoimmune diseases, including pSS [60], but is reserved for life-threatening indications such as thrombotic thrombocytopenic purpura or vasculitis with pulmonary involvement [22, 60-62].

\section{PROGNOSIS}

Based on biopsy series, $10-20 \%$ of patients with pSS and kidney disease develop ESKD $[8,12,63]$. In Kidder et al. [22], although the 3-year renal survival was $92 \%$ in both (TIN and GN) groups, 3 -year patient survival was less in the GN group (66\%) than the TIN group (100\%). The majority of the patients in the study received one form of immune therapy, and complete remission (defined as normalisation of serum creatinine and resolution of urinary sediment abnormalities) was more likely to occur in the TIN group than in the GN group ( $46 \%$ vs $22 \%$, $p$ value 0.4 ). $20 \%$ of each group did not receive any form of treatment, and deterioration in kidney function was observed in all cases (with two reaching ESKD). 


\section{BURDEN AND EFFECTS ON QUALITY OF LIFE}

CKD from any aetiology carries significant morbidity and mortality. In the early stages of CKD, treatment aims to slow or prevent disease progression. However, complications inevitably arise as CKD progresses. Fatigue, insomnia, mental health conditions (anxiety and depression), anorexia, anaemia and disrupted bone biochemistry with consequent bone pain and $\mathrm{CV}$ disease can all complicate advanced kidney disease. Fluid balance management presents a unique challenge as patients with pSS have a constant sensation of a dry mouth.

\section{CONCLUSIONS}

The diversity of symptoms and heterogeneity of kidney disease in pSS makes diagnosis challenging. It is also difficult to institute an effective screening programme. Although TIN carries a better prognosis, optimal management is unknown. Glomerular disease is more aggressive and usually requires immunosuppressive therapy. A greater understanding of pathogenesis, particularly in immune-mediated GN, may guide future disease therapy.

We suggest that clinicians should incorporate regular screening for kidney disease into standard care for patients with pSS by checking renal function, blood pressure, urinalysis and the urine protein:creatinine ratio at presentation. Thereafter, if these tests are all normal, an annual check-dependent upon the individual's circumstances-is likely to suffice. Prompt identification of kidney involvement in pSS should improve prognosis and symptom burden with earlier instigation of monitoring and treatment.

\section{ACKNOWLEDGEMENTS}

The authors would like to thank David Kipgen for providing histology images.
Funding. No funding or sponsorship was received for this study or publication of this article.

Authorship. All named authors meet the International Committee of Medical Journal Editors (ICMJE) criteria for authorship for this article, take responsibility for the integrity of the work as a whole, and have given their approval for this version to be published.

Authorship Contributions. All authors contributed intellectual content and approved the final version of the manuscript.

Disclosures. None of the authors (Oshorenua Aiyegbusi, Laura McGregor, Lucy McGeoch, David Kipgen, Colin C. Geddes, Kathryn I. Stevens) have anything to disclose.

Compliance with Ethics Guidelines. This article is based on previously conducted studies and does not contain any new studies with human participants or animals performed by any of the authors.

Data Availability. Data sharing is not applicable to this article as no datasets were generated or analysed during the current study.

Open Access. This article is licensed under a Creative Commons Attribution-NonCommercial 4.0 International License, which permits any non-commercial use, sharing, adaptation, distribution and reproduction in any medium or format, as long as you give appropriate credit to the original author(s) and the source, provide a link to the Creative Commons licence, and indicate if changes were made. The images or other third party material in this article are included in the article's Creative Commons licence, unless indicated otherwise in a credit line to the material. If material is not included in the article's Creative Commons licence and your intended use is not permitted by statutory regulation or exceeds the permitted use, you will need to obtain permission directly from the copyright holder. To view a copy of this licence, visit http://creativecommons.org/licenses/by$\mathrm{nc} / 4.0 /$. 


\section{REFERENCES}

1. Patel R, Shahane A. The epidemiology of Sjögren's syndrome. Clin Epidemiol. 2014;6:247-55. https:// doi.org/10.2147/CLEP.S47399.

2. Vivino FB. Sjogren's syndrome: clinical aspects. Clin Immunol. 2017;182:48-54. https://doi.org/10. 1016/j.clim.2017.04.005.

3. Bowman SJ. Primary Sjögren's syndrome. Lupus. 2018;27:32-5. https://doi.org/10.1177/ 0961203318801673.

4. Shiboski CH, Shiboski SC, Seror R, Criswell LA, Labetoulle M, Lietman TM, et al. 2016 American College of Rheumatology/European League Against Rheumatism classification criteria for primary Sjögren's syndrome: a consensus and data-driven methodology involving three international patient cohorts. Arthritis Rheumatol. 2017;69(1):35-45. https://doi.org/10.1002/art.39859.

5. Baldini C, Pepe P, Quartuccio L, Priori R, Bartoloni E, Alunno A, et al. Primary Sjögren's syndrome as a multi-organ disease: Impact of the serological profile on the clinical presentation of the disease in a large cohort of Italian patients. Rheumatol (Oxf). 2014;53(5):839-44. rheumatology/ket427.

6. Ramos-Casals M, Solans R, Rosas J, Camps MT, Gil A, Del Pino-Montes J, et al. Primary Sjögren syndrome in Spain: clinical and immunologic expression in 1010 patients. Med (Baltim). 2008;87(4): 210-9. 0b013e318181e6af.

7. Ramos-Casals M, Brito-Zerón P, Seror R, Bootsma H, Bowman SJ, Dörner $\mathrm{T}$, et al. Characterization of systemic disease in primary Sjögren's syndrome: EULAR-SS Task Force recommendations for articular, cutaneous, pulmonary and renal involvements. Rheumatology. 2015;54(12):2230-8. https:// academic.oup.com/rheumatology/article/54/12/ 2230/1792983

8. Ren H, Wang WM, Chen XN, Zhang W, Pan XX, Wang XL, et al. Renal involvement and followup of 130 patients with primary Sjögren's syndrome. J Rheumatol. 2008;35(2):278-84.

9. Vitali C, Bombardieri S, Jonsson R, Moutsopoulos HM, Alexander EL, Carsons SE, et al. Classification criteria for Sjögren's syndrome: a revised version of the European criteria proposed by the AmericanEuropean Consensus Group. Ann Rheum Dis. 2002;61(6):554-8. https://doi.org/10.1136/ard.61. 6.554 .
10. François $H$, Mariette $X$. Renal involvement in primary Sjögren syndrome. Nature Rev Nephrol. 2016;12(2):82-93. https://doi.org/10.1038/nrneph. 2015.174 .

11. Ramos-Casals M, Brito-Zerón P, Solans R, Camps MT, Casanovas A, Sopeña B, et al. Systemic involvement in primary Sjögren's syndrome evaluated by the EULAR-SS disease activity index: Analysis of 921 Spanish patients (GEAS-SS registry). Rheumatol (Oxf). 2014;53(2):321-31. https://doi. org/10.1093/rheumatology/ket349.

12. Goules AV, Tatouli IP, Moutsopoulos HM, Tzioufas AG. Clinically significant renal involvement in primary Sjögren's syndrome: clinical presentation and outcome. Arthritis Rheum. 2013;65(11): 2945-53. https://doi.org/10.1002/art.38100.

13. Abrol E, González-Pulido C, Praena-Fernández JM, Isenberg DA. A retrospective study of long-term outcomes in 152 patients with primary Sjögren's syndrome: 25-year experience. Clin Med J R Coll Phys Lond. 2014;14(2):157-64. https://doi.org/10. 7861/clinmedicine.14-2-157.

14. Bossini N, Savoldi S, Franceschini F, Mombelloni S, Baronio M, Cavazzana I, et al. Clinical and morphological features of kidney involvement in primary Sjögren's syndrome. Nephrol Dial Transplant. 2001;16(12):2328-36. https://doi.org/10.1093/ndt/ 16.12.2328.

15. Lin DF, Yan SM, Zhao Y, Zhang W, Li MT, Zeng XF, et al. Clinical and prognostic characteristics of 573 cases of primary Sjögren's syndrome. Chin Med J (Engl). 2010;123(22):3252-7. https://doi.org/10. 3760/cma.j.issn.0366-6999.2010.22.015.

16. Jain A, Srinivas BH, Emmanuel D, Jain VK, Parameshwaran S, Negi VS. Renal involvement in primary Sjogren's syndrome: a prospective cohort study. Rheumatol Int. 2018;38(12):2251-62. https://doi.org/10.1007/s00296-018-4118-x.

17. Brito-Zerón P, Acar-Denizli N, Zeher M, Rasmussen A, Seror R, Theander E, et al. Influence of geolocation and ethnicity on the phenotypic expression of primary Sjögren's syndrome at diagnosis in 8310 patients: a cross-sectional study from the Big Data Sjögren Project Consortium. Ann Rheum Dis. 2017;76(6):1042-50. https://doi.org/10.1136/ annrheumdis-2016-209952.

18. Maripuri S, Grande JP, Osborn TG, Fervenza FC, Matteson EL, Donadio JV, et al. Renal involvement in primary Sjögren's syndrome: a clinicopathologic study. Clin J Am Soc Nephrol. 2009;4(9):1423-31. https://doi.org/10.2215/CJN.00980209.

19. Pertovaara M, Korpela M, Kouri T, Pasternack A. The occurrence of renal involvement in primary 
Sjogren's syndrome: a study of 78 patients. Rheumatol (Oxf). 1999;38(11):1113-20. https://doi. org/10.1093/rheumatology/38.11.1113.

20. Goules AV, Geetha D, Arend LJ, Baer AN. Renal involvement in primary Sjögren's syndrome: natural history and treatment outcome. Clin Exper Rheumatol. 2019;118(3):123-32.

21. Fujimoto T, Shiiki H, Takahi Y, Dohi K. Primary Sjögren's syndrome presenting as hypokalaemic periodic paralysis and respiratory arrest. Clin Rheumatol. 2001;20(5):365-8. https://doi.org/10. $1007 / \mathrm{s} 100670170028$.

22. Kidder D, Rutherford E, Kipgen D, Fleming S, Geddes C, Stewart GA. Kidney biopsy findings in primary Sjögren syndrome. Nephrol Dial Transplant. 2015;30(8):1363-9. https://doi.org/10.1093/ndt/ gfv042.

23. Cohen EP, Bastani B, Cohen MR, Kolner S, Henriken $\mathrm{P}$, Gluck SL. Absence of $\mathrm{H}+$-ATPase in cortical collecting tubules of a patient with Sjogren's syndrome and distal renal tubular acidosis. J Am Soc Nephrol. 1992;3(2):264-71.

24. Takemoto F, Hoshino J, Sawa N, Tamura Y, Tagami $\mathrm{T}$, Yokota M, et al. Autoantibodies against carbonic anhydrase II are increased in renal tubular acidosis associated with Sjögren syndrome. Am J Med. 2005;118(2):181-4. https://doi.org/10.1016/j. amjmed.2004.07.049.

25. Gu X, Su Z, Chen M, Xu Y, Wang Y. Acquired Gitelman syndrome in a primary Sjögren syndrome patient with a SLC12A3 heterozygous mutation: a case report and literature review. Nephrology. 2017;22(8):652-5. https://doi.org/10.1111/nep. 13045 .

26. Kim YK, Song HC, Kim WY, Yoon HE, Choi YJ, Ki $\mathrm{CS}$, et al. Acquired Gitelman syndrome in a patient with primary Sjögren syndrome. Am J Kidney Dis. 2008;52(6):1163-7. https://doi.org/10.1053/j.ajkd. 2008.07.025.

27. Mishima E, Mori T, Sohara E, Uchida S, Abe T, Ito S. Inherited, not acquired, Gitelman syndrome in a patient with Sjögren's syndrome: importance of genetic testing to distinguish the two forms. CEN Case Rep. 2017;6(2):180-4. https://doi.org/10. 1007/s13730-017-0271-4.

28. Pedro-Botet J, Tomas S, Soriano JC, Coll J. Primary Sjogren's syndrome associated with Bartter's syndrome. Clin Exper Rheumatol. 1991;9(2):210-2.

29. Casatta L, Ferraccioli GF, Bartoli E. Hypokalaemic alkalosis, acquired Gitelman's and Bartter's syndrome in chronic sialoadenitis. Br J Rheumatol.
1997;36(10):1125-8. https://doi.org/10.1093/ rheumatology/36.10.1125.

30. Ahmad Y. Case review of sarcoidosis resembling Sjogren's syndrome. J Clin Med Res. 2010;2(6): 284-8. https://doi.org/10.4021/jocmr482w.

31. Yu TM, Lin SH, Ya-Wen C, Wen MC, Chen YH, Cheng $\mathrm{CH}$, et al. A syndrome resembling Bartter's syndrome in sarcoidosis. Nephrol Dial Transplant. 2009;24(2):667-9. https://doi.org/10.1093/ndt/ gfn600.

32. Evans RDR, Laing CM, Ciurtin C, Walsh SB. Tubulointerstitial nephritis in primary Sjögren syndrome: clinical manifestations and response to treatment. BMC Musculoskelet Disord. 2016;17:2. https://doi.org/10.1186/s12891-015-0858-x.

33. Katsifis GE, Rekka S, Moutsopoulos NM, Pillemer S, Wahl SM. Systemic and local interleukin-17 and linked cytokines associated with Sjögren's syndrome immunopathogenesis. Am J Pathol. 2009;175(3):1167-77. https://doi.org/10.2353/ ajpath.2009.090319.

34. Matsumura R, Kondo Y, Sugiyama T, Sueishi M, Koike T, Takabayashi K, et al. Immunohistochemical identification of infiltrating mononuclear cells in tubulointerstitial nephritis associated with Sjogren's syndrome. Clin Nephrol. 1988;30(6):335-40.

35. Ramos-Casals M, Cervera R, Yague J, Garcia-Carrasco $\mathrm{M}$, Trejo $\mathrm{O}$, Jimenez $\mathrm{S}$, et al. Cryoglobulinemia in primary Sjogren's syndrome: prevalence and clinical characteristics in a series of 115 patients. Semin Arthritis Rheum. 1998;28(3):200-5. https:// doi.org/10.1016/S0049-0172(98)80037-1.

36. Garcia-Carrasco M, Ramos M, Cervera R, Font J, Vidal J, Muñoz FJ, et al. Hepatitis C virus infection in 'primary' Sjogren's syndrome: prevalence and clinical significance in a series of 90 patients. Ann Rheum Dis. 1997;56(3):173-5. https://doi.org/10. 1136/ard.56.3.173.

37. Guellec D, Cornec-Le Gall E, Groh M, Hachulla E, Karras A, Charles P, et al. ANCA-associated vasculitis in patients with primary Sjögren's syndrome: detailed analysis of 7 new cases and systematic literature review. Autoimmun Rev. 2015;14(8): 742-50. https://doi.org/10.1016/j.autrev.2015.04. 009.

38. Puxeddu I, Capecchi R, Carta F, Tavoni AG, Migliorini P, Puxeddu R. Salivary gland pathology in IgG4-related disease: a comprehensive review. J Immunol Res. 2018;2018:6936727. https://doi. org/10.1155/2018/6936727.

39. Deshpande V, Zen Y, Chan JKC, Yi EE, Sato Y, Yoshino $\mathrm{T}$, et al. Consensus statement on the 
pathology of IgG4-related disease. Mod Pathol. 2012;25(9):1181-92. https://doi.org/10.1038/ modpathol.2012.72.

40. Perugino CA, Wallace ZS, Meyersohn N, Oliveira G, Stone JR, Stone JH. Large vessel involvement by IgG4-related disease. Med (Baltim). 2016;95(28): e3344. 0000000000003344

41. Mavragani CP, Fragoulis GE, Rontogianni D, Kanariou M, Moutsopoulos HM. Elevated IgG4 serum levels among primary Sjögren's syndrome patients: do they unmask underlying IgG4-related disease? Arthritis Care Res. 2014;66(5):773-7. https://doi.org/10.1002/acr.22216.

42. Kawano M, Suzuk Y, Yamada K, Mizushima I, Matsumura M, Nakajima K, et al. Primary Sjögren's syndrome with chronic tubulointerstitial nephritis and lymphadenopathy mimicking IgG4-related disease. Mod Rheumatol. 2015;25(4):637-41. https://doi.org/10.3109/14397595.2013.844303.

43. Nakashima Y, Nakamura H, Horai Y, Hayashi T, Takagi Y, Nakamura T, et al. Comorbid case of IgG4related disease and primary Sjögren's syndrome. Mod Rheumatol. 2015;25(3):462-7. https://doi.org/ $10.3109 / 14397595.2013 .843750$

44. Lin CY, Wu CH, Chen HA, Hsu CY, Wang LH, Su YJ. Long-term renal prognosis among patients with primary Sjögren's syndrome and renal involvement: a nationwide matched cohort study. J Autoimmun. 2020;113:102483. https://doi.org/10. 1016/j.jaut.2020.102483.

45. Gera M, Griffin MD, Specks U, Leung N, Stegall MD, Fervenza FC. Recurrence of ANCA-associated vasculitis following renal transplantation in the modern era of immunosupression. Kidney Int. 2007;71(12):1296-301. https://doi.org/10.1038/sj. ki.5002244.

46. Cosio FG, Cattran DC. Recent advances in our understanding of recurrent primary glomerulonephritis after kidney transplantation. Kidney Int. 2017;91(2):304-14. https://doi.org/10.1016/j. kint.2016.08.030.

47. Sens YAS, Malafronte P, Souza JF, Bruno S, Gonzalez RBC, Miorin LA, et al. Cryoglobulinemia in kidney transplant recipients. Transplant Proc. 2005;37(10): 4273-5. https://doi.org/10.1016/j.transproceed. 2005.11.020.

48. Hiesse C, Bastuji-Garin S, Santelli G, Moulin B, Cantarovich M, Lantz O, et al. Recurrent essential mixed cryoglobulinemia in renal allografts: report of two cases and review of the literature. Am J Nephrol. 1989;9(2):150-4. https://doi.org/10.1159/ 000167955.
49. Tarantino A, Moroni G, Banfi G, Ponticelli C, Manzoni C, Segagni S. Renal replacement therapy in cryoglobulinaemic nephritis. Nephrol Dial Transplant. 1994;9(10):1426-30. https://doi.org/10. 1093/oxfordjournals.ndt.a092667.

50. Kasagi T, Nobata H, Ikeda K, Banno S, Ito Y. Successful renal transplantation to a recipient with type II cryoglobulinemia: a case report. BMC Nephrol. 2018;19(1):170. https://doi.org/10.1186/ s12882-018-0966-6.

51. Mafla OC, Jabalquinto RC, Morales MLA, Benot AR, Montemayor VEG, Cabello MDN, et al. Primary Sjögren syndrome associated with mixed cryoglobulinaemia in kidney transplant patient. Transplantation. 2018;102:S86. https://doi.org/10.1097/01. tp.0000542673.19641.04.

52. Lees JS, McQuarrie EP, Mordi N, Geddes CC, Fox JG, Mackinnon B. Risk factors for bleeding complications after nephrologist-performed native renal biopsy. Clin Kidney J. 2017;10(4):573-7. https:// doi.org/10.1093/ckj/sfx012.

53. Seror R, Theander E, Brun JG, Ramos-Casals M, Valim V, Dörner T, et al. Validation of EULAR primary Sjögren's syndrome disease activity (ESSDAI) and patient indexes (ESSPRI). Ann Rheum Dis. 2015;74(5):859-66. https://doi.org/10.1136/ annrheumdis-2013-204615.

54. Devauchelle-Pensec V, Mariette X, Jousse-Joulin S, Berthelot JM, Perdriger A, Puechal X, et al. Treatment of primary Sjögren syndrome with rituximab: a randomized trial. Ann Intern Med. 2014;160(4): 233-42. https://doi.org/10.7326/M13-1085.

55. Pijpe J, Van Imhoff GW, Spijkervet FKL, Roodenburg JLN, Wolbink GJ, Mansour K, et al. Rituximab treatment in patients with primary Sjögren's syndrome: an open-label phase II study. Arthritis Rheum. 2005;52(9):2740-50. https://doi.org/10. 1002/art.21260.

56. Gottenberg JE, Cinquetti G, Larroche C, Combe B, Hachulla E, Meyer O, et al. Efficacy of rituximab in systemic manifestations of primary Sjögren's syndrome: results in 78 patients of the AutoImmune and Rituximab Registry. Ann Rheum Dis. 2013;72(6):1026-31. https://doi.org/10.1136/ annrheumdis-2012-202293.

57. St-Clair EW, Levesque MC, Prak ETL, Vivino FB, Alappatt CJ, Spychala ME, et al. Rituximab therapy for primary Sjögren's syndrome: an open-label clinical trial and mechanistic analysis. Arthritis Rheum. 2013;65(4):1097-106. https://doi.org/10. 1002/art.37850.

58. Schilcher G, Schwarz C, Hermann J. Successful treatment of renal tubular acidosis and recurrent 
secondary struvite kidney stones with rituximab in a patient with primary Sjögren's syndrome. Rheumatol (Oxf). 2017;56(3):498-500. https://doi. org/10.1093/rheumatology/kew452.

59. Terrier B, Krastinova E, Marie I, Launay D, Lacraz A, Belenotti $\mathrm{P}$, et al. Management of noninfectious mixed cryoglobulinemia vasculitis: data from 242 cases included in the CryoVas survey. Blood. 2012;119(25):5996-6004. https://doi.org/10.1182/ blood-2011-12-396028.

60. Karadag O, Soyuoz A, Kalyoncu U, Karaagac T, Kilic L, Kiraz S, et al. FRI0390 therapeutic plasma exchange (TPE) for refractory autoimmune diseases: report of 60 cases. Ann Rheum Dis. 2014;73:528-9. https://doi.org/10.1136/annrheumdis-2014-eular. 4876.
61. Sun $X$, Lu H. Treatment with plasma exchange followed by plasma infusion for thrombotic thrombocytopenic purpura associated with Sjögren's syndrome. Blood. 2016;128(22):4943. https:// doi.org/10.1182/blood.v128.22.4943.4943.

62. Evans R, Zdebik A, Ciurtin C, Walsh SB. Renal involvement in primary Sjögren's syndrome. Rheumatol (Oxf). 2015;54(9):1541-8. https://doi. org/10.1093/rheumatology/kev223.

63. Goules A, Masouridi S, Tzioufas AG, Ioannidis JPA, Skopouli FN, Moutsopoulos HM. Clinically significant and biopsy-documented renal involvement in primary Sjogren syndrome. Med (Baltim). 2000;79(4):241-9. https://doi.org/10.1097/ 00005792-200007000-00005. 